\title{
MulawarmanLawReview
}

\section{Implementasi Green Growth Economic pada Industri Kelapa Sawit melalui Sertifikasi ISPO}

\author{
Rio Christiawan \\ Universitas 17 Agustus 1945, Jakarta, Indonesia. Email: rchristiawan@gmail.com
}

\begin{abstract}
The palm oil industry in Indonesia is a double-edged sword. On one hand, it is the largest contributor to the Indonesian foreign exchange and plays a significant role in the national economy. However, it also has negative impacts to the environment. Debates arising among conservatives in regards to the cultivation of natural resources will not be enough to solve the roots of the problem. The government needs to develop the palm oil industry strategically. In the last ten years the government has repeatedly decided on the certification of sustainable palm oil industry (ISPO certification), but the green growth program is still yet to be realized. This paper is written using the normative-juridical method with focus on legal research regarding the application of green growth concept in the palm oil industry certification. This research shows the lack of transparent regulations pertaining to ISPO certification because so far it is only done voluntarily. Furthermore, the ISPO certification only gives permission without giving any other incentive to the palm oil industry. This shows a stark difference compared to the international certification, the RSPO, which not only mandates the certificate holders to donate but also but provides incentives including premium prices. Thus, the ISPO certification cannot be effectively implemented to support the green growth policy.
\end{abstract}

Keywords: Certification; Sustainability; ISPO.

\begin{abstract}
ABSTRAK
Industri kelapa sawit merupakan industri strategis nasional karena selain sebagai penyumbang devisa terbesar juga memiliki dampak besar terhadap perekonomian di Indonesia. Tidak dapat dikesampingkan fakta bahwa industri kelapa sawit juga menimbulkan sejumlah dampak negatif bagi lingkungan. Perdebatan dari kalangan konservasitisme dan developmentalis terkait kelanjutan pengelolaan sumber daya alam tidak akan menyelesaikan akar masalah sebenarnya. Pemerintah perlu mengatur kelanjutan pengembangan industri strategis kelapa sawit. Persaoalan dalam penulisan ini adalah pemerintah dalam sepuluh tahun terakhir berkali-kali membatalkan aturan tentang sertifikasi industri kelapa sawit yang lestari (sertifikasi ISPO) akibatnya pendekatan green growth economic belum dapat terwujud pada industri kelapa sawit. Metode Penulisan dalam penelitian ini yuridis normatif dengan fokus melakukan kajian yuridis terhadap implementasi konsep hukum lingkungan green growth economic terhadap kebijakan sertifikasi pada industri kelapa sawit. Hasil kajian penelitian ini menunjukkan aturan yang tidak jelas dan mengikat terkait sertifikasi ISPO (hanya bersifat voluntary). Selain itu sertifikasi ISPO hanya memberi kewajiban tanpa memberi insentif apapun bagi industri kelapa sawit. Hal ini berbeda jika dibandingkan dengan sertifikasi internasional yakni RSPO, selain memberi kewajiban tetapi juga mampu memberikan insentif berupa harga yang premium menyebabkan sertifikasi ISPO tidak dapat diterapkan secara efektif guna menunjang green growth economic.
\end{abstract}

Kata kunci: Sertifikasi; Kelestarian; ISPO. 
Citation: Christiawan, Rio. 2020. "Implementasi Green Growth Economic Pada Industri Kelapa Sawit Melalui Sertifikasi ISPO". Mulawarman Law Review 5 (1), 47-60. https://doi.org/10.30872/mulrev.v5i1.323.

\section{PENDAHULUAN}

Pendekatan green growth economic dalam hukum lingkungan pertama kali dikenal dalam KTT Bumi (Earth Summit) di Rio de Janerio, Brasil, pada tahun 1992, yang menegaskan mengenai konsep pembangunan berkelanjutan (sustainability development). Pembangunan berkelanjutan sebagaimana dikenal dengan green growth economic merupakan bentuk kompromi antara kepentingan konservasi dan kepentingan pemanfaatan sumberdaya alam untuk kepentingan komersial. Kalangan pro konservasi berpandangan dengan mengacu pada doktrin hukum in dubio pro natura, yakni dalam keraguan harus diambil kebijakan yang menguntungkan lingkungan. ${ }^{1}$

Konservasi dipandang sebagai bentuk keberpihakan pada lingkungan karena dipandang sebagai bentuk perlindungan lingkungan dan sumberdaya alam dari segala bentuk pemanfaatan yang menyebabkan degradasi kualitas lingkungan. Sebaliknya dengan mengacu pada konstitusi Pasal 33 UUD 1945 bahwa pemanfaatan lingkungan dan sumberdaya alam dapat dimanfaatkan untuk kesejahteraan rakyat.

Demikian juga dalam hal ini industri perkebunan dan pengolahan kelapa sawit yang menjadi penyumbang devisa terbesar saat ini, berikut adalah sumbangan devisa negara dari sektor kelapa sawit ${ }^{2}$.

Tabel 1. Tabel devisa dari sektor sawit 2015 - 2019

\begin{tabular}{|c|c|}
\hline Tahun & Jumlah Devisa \\
\hline 2015 & USD 21 Miliar \\
\hline 2016 & USD 22,7Miliar \\
\hline 2017 & USD 23 Miliar \\
\hline 2018 & USD 24,3 Miliar \\
\hline 2019 & USD 27 Miliar \\
\hline
\end{tabular}

Sumber : Gapki (2019)

Industri kelapa sawit dimulai di Indonesia sejak tahun 1600-an serta melalui dua masa penjajahan yakni penjajahan Belanda dan Jepang, sehingga semangat dari industri kelapa sawit pada masa penjajahan adalah eksploitasi, termasuk eksploitasi lingkungan (pengelolaan hanya difokuskan pada eksploitasi hasil, hanya berfokus pada profit

1 Jeremy Kartz. (2015). "Green Growth Economic as a New Environmental Paradigm". International and Comparative Law Quarterly Journal, 70 (1): 89.

2 https://gapki.id/news/4419/sawit-sumbang-devisa-300-triliun-untuk-negeri-ini-apa-maknanya diunduh pada 29 Juni 2020 
oriented). ${ }^{3}$ Selanjutnya setelah Indonesia merdeka maka semangat pengelolaan industri kelapa sawit berbeda dengan pada masa penjajahan. Jika pada fase sebelum kemerdekaan semangat pengelolaan industri adalah eksploitasi, namun setelah kemerdekaan dengan berdasarkan Pasal 33 UUD 1945 mulai merubah paradigma pengelolaan lingkungan dan sumberdaya alam khususnya pada industri kelapa sawit.

Paradigma baru setelah kemerdekaan adalah hanya keseimbangan antara perlindungan terhadap lingkungan dan sumberdaya alam serta aspek pemanfaatan maupun pengelolaan sumberdaya alam itu sendiri. Paradigma single bottom line yang hanya berorientasi pada keuntungan saja (profit oriented) mulai ditinggalkan dan diganti dengan paradigma green growth economic. Paradigma green growth economic memiliki tujuan kelestarian (sustainability), baik sustainability perlindungan lingkungan maupun keberlanjutan dalam pemanfaatan sumberdaya alam itu sendiri. Paradigma ini mencoba membangun kompromi antara perlindungan lingkungan (kepentingan konservasi) dan pemanfaatan sumberdaya alam untuk kesejahteraan masyarakat.

Parameter green growth economic baru ditentukan secara khusus pada Konvensi Yohannesburg pada tahun 2002 yang merubah paradigma single bottom line menjadi triple bottom line yakni people, profit, and planet yang selanjutnya dituangkan dalam Undang-Undang Nomor 18 Tahun 2004 tentang Perkebunan. ${ }^{4}$ Di awal tahun 2004, dunia internasional menyepakati konsep sertifikasi kelapa sawit sebagai tindak lanjut dari green growth economic yakni sertifikasi kelestarian pengelolaan industri kelapa sawit yakni sertifikasi Roundtable on Sustainable Palm Oil (RSPO). ${ }^{5}$ Sifat dari sertifikasi RSPO itu sendiri adalah voluntary (tidak wajib), namun sertifikasi RSPO diterima di dunia internasional karena memiliki nilai tambah (additional value) yakni dengan sertifikasi RSPO dapat diperoleh kemudahan distribusi dan harga yang premium.

Di Indonesia sendiri implementasi dari pendekatan green growth economic baru diawali di tahun 2011 dengan penuangan konsep pemenuhan triple bottom line untuk memastikan kelestarian industri kelapa sawit melalui penjabaran triple bottom line dalam prinsip dan kriteria dalam sertifikasi Indonesian Sustainable Palm Oil (ISPO) yang bersifat mandatory (wajib). ${ }^{6}$ Sertifikasi ISPO sendiri di Indonesia diatur dalam Peraturan Menteri Pertanian Nomor 19/Permentan/OT.140/3/2011 yang merupakan turunan dari Undang-Undang Nomor 18 Tahun 2004 tentang Perkebunan.

Dalam Peraturan Menteri Pertanian Nomor 19/Permentan/OT.140/3/2011 dijelaskan bahwa diberikan waktu hingga tahun 2015 untuk pemenuhan sertifikasi ISPO dan jika pada kurun waktu yang ditetapkan tersebut bagi pengelolaan kelapa sawit yang belum memperoleh sertifikat ISPO akan dicabut perizinannya. Perusaaan pengelola industri kelapa sawit hanya sekitar 2 persen yang memperoleh sertifikasi ISPO hingga akhir

3 Iyung Pahan. (2007). Panduan Lengkap Kelapa Sawit: Manajemen Agribisnis dari Hulu hingga Hilir, Cetakan Pertama. Penerbit Penebar Swadaya, p. 44-45.

4 Undang-Undang Nomor 18 Tahun 2004 tentang Perkebunan saat ini telah dicabut dan diganti dengan Undang-Undang Nomor 39 Tahun 2014 tentang Perkebunan.

5 Salahudin Yacob, et. al. (2012). Handbook of RSPO Certification, $1^{\text {st }}$ Edition. Kuala Lumpur: RSPO Publishing.

6 Sundram Kumar. (2014). "Comparison between RSPO and ISPO and Their Impact for Palm Oil Industry". Journal of Oil Palm, Environmental and Health, 8(2): 162. 
tahun $2014 .^{7}$ Fakta ini menghambat pemerintah untuk melakukan tindakan penegakan hukum pada pengelola industri kelapa sawit yang belum memenuhi syarat pemenuhan sertifikasi ISPO.

Peraturan Menteri Pertanian Nomor 19/Permentan/OT.140/3/2011 tidak dapat diterapkan karena pencapaian sertifikasi ISPO masih sangat rendah maka pemerintah menerbitkan Peraturan Menteri Pertanian Nomor 11/Permentan/OT.140/3/2015 yang hanya mewajibkan pendaftaran proses sertifikasi ISPO bukan diperolehnya sertifikasi ISPO sebagaimana diatur dalam Peraturan Menteri Pertanian Nomor 19/Permentan/OT.140/3/2011. Akibatnya hingga lima tahun berselang yakni pada 2019 jumlah perolehan sertifikasi ISPO hanya meningkat dari 2 persen pada 2014 menjadi 10 persen dari total perusahaan/ plasma pengelola industri kelapa sawit, dengan rincian sebagai berikut ${ }^{8}$ :

Tabel 2. Persentasi Perusahaan Perkebunan yang Memperoleh Sertifikat ISPO

\begin{tabular}{cc}
\hline Tahun & $\begin{array}{c}\text { Jumlah Persentasi Perusahaan } \\
\text { Perkebunan yang Memperoleh } \\
\text { Sertifikat ISPO (\%) }\end{array}$ \\
\hline 2014 & 2 \\
\hline 2015 & 2,8 \\
\hline 2016 & 3 \\
\hline 2017 & 5 \\
\hline 2018 & 8 \\
\hline 2019 & 10 \\
\hline
\end{tabular}

Sumber: Laporan Tahunan Industri Strategis Nasional Kemenko Perekonomian. Jakarta: KemenkoPerekonomian (2020)

Situasi ini jelas menunjukkan bahwa ada gap antara implementasi paradigma green growth economic sebagai das sollen dan fakta belum terimplementasikan green growth economic dalam sertifikasi industri kelapa sawit secara optimal sebagai das sein. Dengan mengacu pada data data diatas artikel ini akan membahas mengenai efektifitas sistem sertifikasi ISPO dalam implementasi konsep green growth economic dalam industri kelapa sawit.

\section{METODE}

Metode yang digunakan dalam tulisan ini adalah metode penulisan yuridis normatif dengan fokus melakukan kajian yuridis terhadap implementasi konsep hukum lingkungan yakni green growth economic terhadap kebijakan sertifikasi pada industri kelapa sawit. Untuk mencapai maksud di atas digunakan studi kepustakaan, yaitu

7 Roesdiana Soeharto. (2015). Laporan Tahunan Komisi ISPO, Cetakan Pertama. Jakarta: Direktorat Jenderal Perkebunan.

${ }^{8}$ Musdalifah. (2020). Laporan Tahunan Industri Strategis Nasional Kemenko Perekonomian. Jakarta: Kemenko Perekonomian, p. 109. 
menggunakan bahan hukum untuk menjawab persoalan yang dibahas. Tulisan ini menggunakan pendekatan penelitian hukum normatif dengan melakukan abstraksi terhadap proses deduksi dari norma hukum positif yang berlaku, yaitu meneliti hukum sebagai norma positif dengan menggunakan cara berpikir deduktif dan berdasarkan pada kebenaran koheren, di mana kebenaran dalam penelitian ini sudah dinyatakan kredibel tanpa harus melalui proses pengujian atau verifikasi.

Data yang dimaksudkan dalam penulisan ini adalah bahan-bahan atau fakta-fakta atau bisa juga diartikan sebagai sumber informasi. Sedangkan bahan hukum yang dimaksudkan dalam penelitian ini terdiri dari bahan hukum primer dan bahan hukum sekunder. Bahan hukum primer adalah merupakan bahan hukum yang bersifat autoritatif artinya mempunyai otoritas peraturan perundangan, risalah atau catatan resmi, dan putusan pengadilan. Sedangkan yang dimaksud bahan hukum sekunder adalah buku-buku (pendapat ahli), jurnal, dan segala sesuatu yang dapat memberikan petunjuk bagi penulis. Data yang diperoleh dianalisis sehingga dapat ditemukan alasan yang rasional mengenai permasalahan yang permasalahan. Dari hasil pengolahan tersebut dianalisis dan kemudian dilakukan pembahasan dan ditarik kesimpulan terhadap implementasi konsep hukum lingkungan yakni green growth economic terhadap kebijakan sertifikasi pada industri kelapa sawit.

\section{PEMBAHASAN}

\section{Green Growth Economic}

Munculnya paradigma green growth economic sendiri dipandang sebagai bentuk kompromi (antara konservasi dan development). Green growth economic sendiri secara filosofis menekankan pada aspek restorasi, yakni pemanfaatan sumberdaya alam dengan pembenahan lingkungan sebagai dampak pemanfaatan sumberdaya alam tersebut. ${ }^{9}$ Definisi kelestarian (sustainability) adalah pemanfaatan sumberdaya alam dengan disertai dengan restorasi (pembenahan) atas dampak negatif atas lingkungan sebagai akibat dari pemanfaatan sumberdaya alam tersebut. ${ }^{10}$

Dalam perkembangannya paradigma green growth economic masih dipandang abstrak untuk diterapkan dalam implementasi pengelolaan sumberdaya alam sehingga paradigma green growth economic dalam Konvensi Yohannesburg pada tahun 2002 dijabarkan dalam triple bottom line (people, profit, and planet). Secara hukum, kedudukan paradigma lebih abstrak jika dibanding dengan asas (principles) ${ }^{11}$ sedangkan dalam hal ini kedudukan triple bottom line adalah sebagai asas di dalam hukum bukan norma yang menjadi pedoman perilaku manusia. Asas hukum hanya

9 A. G. Wibisana. (2017). “Campur Tangan Pemerintah dalam Pengelolaan Lingkungan: Sebuah Penelusuran Teoritis berdasarkan Analisis Ekonomi atas Hukum (Economic Analysis of Law)". Jurnal Hukum dan Pembangunan Universitas Indonesia, 47(2): 160.

10 Raymond Yong Leong. (2015). "Correlation between Environmental Law and Sustainability Aspect in Tropical Countries". University of Malaya Law Review Journal, 51: 97.

11 B. Arief Sidharta. "Struktur Ilmu Hukum", dalam Esmi Warassih dkk (ed). (2012). Refleksi dan Rekonstruksi Ilmu Hukum di Indonesia. Semarang: Penerbit Bagian Hukum dan Masyarakat Fakultas Hukum Universitas Diponegoro, p. 44. 
menjadi landasan bagi peraturan hukum konkret (norma), tetapi asas hukum bukan norma hukum. ${ }^{12}$

Dalam hal ini paradigma green growth economic dengan asas triple bottom line harus dituangkan dalam peraturan konkret sebagai parameter implementasinya di dalam masyarakat. Esensi dari green growth economic adalah restorasi, mengingat tidak mungkin dicapai kelestarian (sustainability) tanpa adanya restorasi (pemulihan lingkungan). Jadi dalam hal ini triple bottom line merupakan asas atau prinsip dasar dari green growth economic itu sendiri. Dapat dikatakan dalam hal ini bahwa paradigma green growth economic dijabarkan dalam tiga asas yang tercantum dalam triple bottom line sebagaimana disepakati dalam Konvensi Yohannesburg pada tahun 2002.

Triple bottom line yang mendasari paradigma green growth economic terdiri dari unsur people, profit, and planet. People, artinya bahwa tidak boleh ada eksploitasi manusia pada pemanfaatan sumberdaya alam karena pada esensinya pemanfaatan sumberdaya alam harus dapat dipergunakan untuk kesejahteraan sebanyak mungkin manusia. Planet, artinya pemanfaatan sumberdaya alam tidak boleh merusak lingkungan atau menyebabkan penurunan kualitas lingkungan (degradasi lingkungan). Pada aspek planet inilah terletak esensi restorasi lingkungan dari pemanfaatan sumberdaya alam, jadi dalam paradigma green growth economic, bahwa sumberdaya alam tidak sekedar dieksploitasi tetapi juga dibarengi dengan tindakan restorasi sebagai bentuk pemulihan kualitas lingkungan. Aspek ini mewakili pemaknaan istilah 'green' dalam paradigma green growth economic.

Unsur terakhir adalah profit, yang artinya pemanfaatan sumberdaya alam harus dapat mendatangkan keuntungan secara ekonomis. Pada esensinya pemanfaatan sumberdaya alam harus dapat dipergunakan untuk kesejahteraan sebanyak mungkin masyarakat. Unsur ini mewakili pemaknaan 'growth economic' dalam paradigma green growth economic. Terlihat bahwa paradigma profit oriented (single bottom line) sudah mulai digantikan dengan paradigma green growth economic yang terdiri dari triple bottom line.

Paradigma green growth economic merupakan paradigma hasil kompromi yang ideal karena terdiri dari dua filosofi yakni 'green' yang mewakili kepentingan untuk menjaga kualitas lingkungan dan aspek restorasi (pemulihan) lingkungan hidup di dalamnya. Sebaliknya, filosofis 'growth economic' meletakkan prinsip keadilan dalam hubungan manusia dan alamnya, yakni pemanfaatan sumberdaya alam tidak boleh dilakukan dengan eksploitasi manusia dan sebaliknya manusia juga tidak boleh melakukan eksploitasi pada lingkungan. ${ }^{13}$ Sebaliknya dalam hal ini unsur profit juga dimaknai sebagai bagian dari kesejahteraan manusia maupun sebagai bagian dari pemulihan lingkungan (restorasi). Pada akhirnya triple bottom line harus diartikan sebagai satu kesatuan dalam paradigma green growth economic.

12 C. A. Van Peursen. (2015). Filsafat Ilmu-Ilmu, diterjemahkan Bernard Arief Sidharta. Bandung: Penerbit Pusat Kajian Humaniora Universitas Katolik Parahyangan, p. 86.

13 Hoogan Kevee. (2013). "Understanding Green Economic Growth in the Perspective of Legal Philosophy in Shifting the Paradigm of Environmental Law". American Journal of Comparative Law, 70(2): 190. 
Dalam industri perkebunan paradigma green growth economic pertama kali dikenal dalam naskah akademik Undang-Undang Nomor 18 Tahun 2004 tentang Perkebunan yang merupakan bentuk tindak lanjut dari Konvensi Yohannesburg pada tahun 2002. Dalam naskah akademik Undang-Undang Nomor 18 Tahun 2004 dijelaskan bahwa industri perkebunan harus menuju pada pengelolaan berbasis green growth economic untuk mewujudkan pengelolaan perkebunan yang bersifat lestari (sustain). ${ }^{14}$

Dalam rumpun industri perkebunan, industri kelapa sawit merupakan salah satu industri yang paling banyak mendapatkan sorotan (baik sorotan positif maupun negatif). Guna menghindari dampak negatif akibat industri kelapa sawit maka pemerintah Indonesia dalam rangka memastikan terimplementasinya green growth economic dalam industri kelapa sawit maka pemerintah membentuk sertifikasi ISPO dan menambahkan satu komisi di bawah dirjen perkebunan yakni komisi ISPO. ${ }^{15}$ Dunia internasional jauh lebih dahulu dalam merespon paradigma pengelolaan kelapa sawit berbasis green growth economic yang disepakati dalam Konvensi Yohannesburg pada tahun 2002, hal ini dibentuknya sertifikasi RSPO pada tahun 2004.

Di Indonesia sistem sertifikasi untuk memastikan paradigma green growth economic diimplementasikan dalam pengelolaan industri kelapa sawit pertama kali dikenal dalam sertifikasi ISPO yang dibentuk berdasarkan Peraturan Menteri Pertanian Nomor 19/Permentan/OT.140/3/2011. Dalam sertifikasi ISPO versi pertama dapat dikatakan seluruh prinsip dan kriteria pemenuhan sertifikasi ISPO yang tercantum dalam Peraturan Menteri Pertanian Nomor 19/Permentan/OT.140/3/2011 mengadopsi prinsip dan kriteria pemenuhan sertifikasi RSPO yang jauh lebih dahulu ada. ${ }^{16}$

Dalam hal penerapan paradigma green growth economic dalam pengelolaan industri sawit terdapat perbedaan antara dunia internasional melalui sertifikasi RSPO dan Indonesia melalui sertifikasi ISPO. Sifat sertifikasi RSPO adalah voluntary namun memberikan insentif secara komersial seperti kemudahan distribusi hingga harga yang premium. Filosofis dari sertifikasi RSPO adalah selain pelaku industri dituntut untuk memenuhi unsur 'green' melalui fokus pada unsur planet, tidak adanya eksploitasi (people) tetapi secara industri kelapa sawit juga perlu ditumbuhkan yakni dengan pemberian insentif secara komersial bagi pengelola industri kelapa sawit yang telah memperoleh sertifikat RSPO, sehingga terpenuhi unsur 'growth economic' dalam paradigma green growth economic. ${ }^{17}$ Sebaliknya di Indonesia melalui Peraturan Menteri Pertanian Nomor 19/Permentan/OT.140/3/2011 sertifikasi ISPO diterapkan secara wajib (mandatory) namun tidak memberikan insentif komersial bagi keberlangsungan industri kelapa sawit itu sendiri.

14 Minuta Rapat Dengar Pendapat antara Tim Penyusun Naskah Akademik Undang-Undang Nomor 18 Tahun 2004 tentang Perkebunan dengan DPR RI, Selasa 20 Januari 2004.

15 Minuta Rapat Kelompok Kerja (Pokja), Pembentukan Komisi ISPO pada Direktorat Jenderal Perkebunan, 22 April 2009.

16 Soelthon Gussetya Nanggara et. al. (2017). Evaluasi 6 Tahun ISPO. Forest Watch Indonesia, p. 33.

17 Darrel Webber. (2015). Opportunities and Challenges in Managing the Palm Oil Industry in Compliance with RSPO Certificate, $1^{\text {st }}$ Edition. Kuala Lumpur: RSPO Publishing. 


\section{Evaluasi 10 Tahun Sertifikasi ISPO}

Pada dasarnya sertifikasi dimaksudkan agar praktik dalam perkebunan dan pengolahan kelapa sawit mengedepankan kelestarian (sustainability) sehingga paradigma green growth economic dan asas triple bottom line perlu dipastikan untuk diterapkan dalam industri kelapa sawit. Sertifikasi ISPO pertama kali diatur melalui Peraturan Menteri Pertanian Nomor 19/Permentan/OT.140/3/2011 dengan sifat penerapan wajib (mandatory), artinya seluruh perusahaan yang mengelola industri kelapa sawit beserta petani plasma wajib mendapat sertifikat ISPO dalam waktu 5 tahun sejak Permentan tersebut.

Prinsip dan Kriteria yang merupakan jabaran dari triple bottom line tersebut dimuat dalam Lampiran I Peraturan Menteri Pertanian Nomor 19/Permentan/OT.140/3/2011. Persoalannya kala itu komisi ISPO tidak benar-benar menyusun prinsip dan kriteria yang dipergunakan dengan menyesuaikan pada kondisi perusahaan perkebunan dan petani plasma di Indonesia dan bahkan hanya mengadopsi secara persis prinsip dan kriteria sertifikasi RSPO. ${ }^{18}$ Demikian juga sifat sertifikasi ISPO yang wajib atau mandatory tanpa memberikan manfaat apapun bagi pemegang sertifikat ISPO selain membuat sertifikasi ISPO tidak mewakili paradigma green growth economic juga membuat sertifikasi ISPO kehilangan daya tarik dibanding RSPO. ${ }^{19}$

Rendahnya pemenuhan sertifikasi ISPO sampai dengan akhir 2014 (sekitar 2 persen) membuat pemerintah tidak melakukan penegakan hukum sebagaimana disebutkan dalam Peraturan Menteri Pertanian Nomor 19/Permentan/OT.140/3/2011 bahwa dalam lima tahun sejak Permentan tersebut jika pengelola perkebunan dan pengolahan kelapa sawit tidak memperoleh sertifikat ISPO akan dicabut seluruh perizinannya. Pada situasi tersebut pemerintah lebih memilih mengganti aturan dibandingkan dengan menegakkan aturan sertifikasi yang telah dibuat, hal ini menunjukkan bahwa dalam Peraturan Menteri Pertanian Nomor 19/Permentan/OT.140/3/2011 terkandung kekeliruan yang fundamental dalam mengimplementasikan paradigma green growth economic dalam praktik industri kelapa sawit.

Selanjutnya pemerintah menerbitkan Peraturan Menteri Pertanian Nomor 11/Permentan/OT.140/3/2015 yang justru lebih menyimpang dari paradigma green growth economic mengingat pada Permentan tersebut pengelola industri kelapa sawit tidak diwajibkan untuk memperoleh sertifikat ISPO, namun hanya diwajibkan untuk mendaftar pada sertifikasi ISPO tanpa kewajiban memperoleh sertifikasi ISPO. Dampak dari Peraturan Menteri Pertanian Nomor 11/Permentan/OT.140/3/2015 adalah perusahaan pengelola industri kelapa sawit maupun petani plasma semakin enggan untuk memenuhi kewajiban pemenuhan sertifikasi ISPO. Secara empiris perusahaan pengelola industri kelapa sawit maupun petani plasma hanya mendaftarkan diri tanpa

18 Op. Cit. Soelthon Gussetya Nanggara et. al., p. 76.

19 Tan Wisakha. (2016). "Comparing ISPO and RSPO Sustainability Certification Practices in the Palm Oil Industry". Journal of Oil Palm Research, 28: 152. 
menindaklanjuti untuk pemenuhan sertifikasi ISPO (sekedar menggugurkan kewajiban pada Peraturan Menteri Pertanian Nomor 11/Permentan/OT.140/3/2015). ${ }^{20}$

Demikian juga pada era Peraturan Menteri Pertanian Nomor 11/Permentan/OT.140/3/2015 meskipun syarat dilonggarkan namun juga tidak diiringi dengan pemberian insentif bagi perusahaan atau petani plasma yang telah mendapat sertifikasi ISPO. Peraturan Menteri Pertanian Nomor 11/Permentan/OT.140/3/2015 dapat dikatakan lebih menyimpangi paradigma green growth economic jika dibandingkan Peraturan Menteri Pertanian Nomor 19/Permentan/OT.140/3/2011. Setidaknya meskipun Peraturan Menteri Pertanian Nomor 19/Permentan/OT.140/3/2011 tidak memberi insentif komersial bagi pemenuhan sertifikasi ISPO tetapi paling tidak bersifat wajib untuk memastikan adanya restorasi dan menghindari eksploitasi sumberdaya alam yang merusak lingkungan (perlindungan aspek people dan planet).

Sebaliknya, dalam Peraturan Menteri Pertanian Nomor 11/Permentan/OT.140/3/2015 justru dibuat tanpa arah dan terkesan hanya untuk menghindari adanya penegakan hukum berdasarkan Peraturan Menteri Pertanian Nomor 19/Permentan/OT.140/3/2011 sehingga Permentan tersebut dicabut dan diganti dengan Peraturan Menteri Pertanian Nomor 11/Permentan/OT.140/3/2015. Dapat dikatakan bahwa Peraturan Menteri Pertanian Nomor 11/Permentan/OT.140/3/2015 jauh menyimpangi bahkan tidak menggambarkan paradigma green growth economic. Tidak adanya insentif dan juga tidak adanya sifat wajib dalam pemenuhan sertifikasi ISPO justru menunjukkan bahwa Peraturan Menteri Pertanian Nomor 11/Permentan/OT.140/3/2015 mengabaikan prinsip triple bottom line (people, profit, and planet) dalam praktik industri kelapa sawit.

Muatan aturan dalam Peraturan Menteri Pertanian Nomor 11/Permentan/OT.140/3/2015 juga bertentangan dengan Undang-Undang Nomor 39 Tahun 2014 tentang Perkebunan, dalam perkembangannya Undang-Undang Nomor 18 Tahun 2004 tentang Perkebunan dicabut dan diganti dengan Undang-Undang Nomor 39 Tahun 2014 tentang Perkebunan. Paradigma green growth economic secara eksplisit diatur dalam Pasal 3 huruf (g) Undang-Undang Nomor 39 Tahun 2014 mengatur bahwa tujuan praktik perkebunan adalah mengelola dan mengembangkan sumberdaya perkebunan secara optimal, bertanggung jawab, dan lestari. Hal ini berbeda dengan Undang-Undang Nomor 18 Tahun 2004 tentang Perkebunan yang hanya menyebutkan paradigma green growth economic dalam bagian umum penjelasan Undang-Undang Nomor 18 Tahun 2004.

Dengan tidak terakomodirnya paradigma green growth economic melalui pemenuhan prinsip triple bottom line dalam praktik perkebunan maka selain sudah menyimpang dari tujuan sertifikasi, dalam hal ini Peraturan Menteri Pertanian Nomor 11/Permentan/OT.140/3/2015 juga cacat hukum karena bertentangan dengan Pasal 3 huruf (g) Undang-Undang Nomor 39 Tahun 2014 yang sesungguhnya merupakan landasan hukum bagi terbitnya Peraturan Menteri Pertanian Nomor

20 Musdalifah. (2019). Materi Focus Group Discussion (FGD) Penyusunan Perpres ISPO, Kantor Kementerian Koordinator Perekonomian, 5 Maret 2019, p. 2. 
11/Permentan/OT.140/3/2015. Sampai pada fase ini paradigma green growth economic sebagaimana diuraikan dalam Pasal 3 huruf (g) Undang-Undang Nomor 39 Tahun 2014 belum dapat diimplementasikan dalam praktik pengelolaan industri kelapa sawit sebagaimana ditetapkan dalam Peraturan Menteri Pertanian Nomor 11/Permentan/OT.140/3/2015.

Peraturan Menteri Pertanian Nomor 11/Permentan/OT.140/3/2015 dipandang kontraproduktif dan terbukti paradigma green growth economic belum diterapkan dalam praktik perkebunan kelapa sawit maka pemerintah harus mengembalikan paradigma green growth economic dalam praktik pengelolaan industri kelapa sawit melalui peraturan yang konkret. ${ }^{21}$ Selanjutnya Presiden menerbitkan Peraturan Presiden (Perpres) Nomor 44 Tahun 2020 tentang Sistem Sertifikasi Perkebunan Kelapa Sawit Berkelanjutan yang mewajibkan baik perusahaan pengelola industri kelapa sawit maupun petani plasma wajib untuk memenuhi prinsip dan kriteria dalam sertifikat ISPO dan mendapatkan sertifikat ISPO.

Peraturan Presiden (Perpres) Nomor 44 Tahun 2020 dapat dikatakan sebagai bentuk perbaikan dari Peraturan Menteri Pertanian Nomor 11/Permentan/OT.140/3/2015 karena setidaknya dalam Perpres tersebut telah mengembalikan sifat wajib (mandatory) bagi pemenuhan sertifikasi ISPO. Dalam hal ini perlu diingat bahwa persoalan prinsip dan kriteria sebagai jabaran triple bottom line untuk dilaksanakan dalam praktik pengelolaan industri sawit masih mengacu pada Peraturan Menteri Pertanian Nomor 11/Permentan/OT.140/3/2015. ${ }^{22}$ Artinya dalam hal ini setelah diterbitkannya Peraturan Presiden (Perpres) Nomor 44 Tahun 2020 masih harus ditindaklanjuti dengan penerbitan peraturan di tingkat operasional setingkat Peraturan Menteri untuk menggantikan Peraturan Menteri Pertanian Nomor 11/Permentan/OT.140/3/2015.

Demikian juga pada aspek formal juga perlu dilakukan evaluasi pada proses birokrasi di Komisi ISPO itu sendiri, mengingat pemenuhan sertifikasi ISPO juga rata-rata memakan waktu yang relatif panjang antara 1,5 tahun hingga 2,5 tahun bahkan lebih. ${ }^{23}$ Sebaliknya tanpa insentif komersial dalam sertifikasi ISPO akan membuat paradigma green growth economic sulit diterapkan dalam praktik pengelolaan industri kelapa sawit mengingat hambatan dan syarat pemenuhan sertifikasi ISPO yang berat namun tanpa disertai dengan manfaat konkret penerima sertifikat ISPO.

Pemerintah perlu segera melakukan tindak lanjut atas terbitnya Peraturan Presiden (Perpres) Nomor 44 Tahun 2020 dengan Peraturan Menteri yang selain harus mencabut Peraturan Menteri Pertanian Nomor 11/Permentan/OT.140/3/2015 yang kontraproduktif, peraturan menteri tersebut nantinya juga harus dapat menetapkan standar prinsip dan kriteria yang tepat dengan kondisi industri kelapa sawit di

21 Minuta Rapat Kelompok Kerja (Pokja), Penyusunan Perpres ISPO, Kantor Kementerian Koordinator Perekonomian, 15 Mei 2019.

22 Peraturan Presiden (Perpres) Nomor 44 Tahun 2020 tidak mencabut Peraturan Menteri Pertanian Nomor 11/Permentan/OT.140/3/2015.

23 Hidayat et. al. (2018). Laporan Tahunan Komisi ISPO Tahun 2017. Penerbit Direktorat Jenderal Perkebunan Kementerian Pertanian, p. 89. 
Indonesia sebagai jabaran dari triple bottom line (tidak sekedar mengadopsi prinsip dan kriteria dalam sertifikasi RSPO).

Kondisi sebagaimana yang terjadi karena diakibatkan regulasi yang tidak konsisten sebagaimana terlihat dalam Peraturan Menteri Pertanian Nomor 19/Permentan/OT.140/3/2011 dan Peraturan Menteri Pertanian Nomor 11/Permentan/OT.140/3/2015 harus dihindari. Demikian juga dengan dasar hukum yang tegas maka penegakan hukum juga dapat dilakukan secara tegas sehingga dengan penegakan hukum yang tegas maka restorasi akan dapat dipastikan terjadi dan praktik pengelolaan industri kelapa sawit tidak merusak lingkungan (menghindari terjadinya eksploitasi lingkungan maupun eksploitasi manusia dalam praktik pengelolaan industri kelapa sawit).

Sebaliknya bagi pengelola industri kelapa sawit yang memenuhi standar pemenuhan sertifikasi harus diberikan insentif secara komersial, sehingga pemenuhan sertifikasi ISPO nantinya akan dapat berkorelasi positif pada pertumbuhan industri itu sendiri (selain terpenuhi unsur 'green' dalam hal ini juga terpenuhi unsur 'growth economic'. Artinya peraturan menteri yang nantinya diterbitkan sebagai tindak lanjut dari Peraturan Presiden (Perpres) Nomor 44 Tahun 2020 harus mengatur juga mengenai sanksi dan insentif komersial maupun non komersial bagi pengelola industri kelapa sawit.

Dengan demikian maka akan ada dorongan dari pengelola industri kelapa sawit untuk memenuhi persyaratan praktik pengelolaan industri kelapa sawit sebagaimana dipersyaratkan dalam aturan sertifikasi ISPO. Jika luasan lahan industri kelapa sawit yang bersertifikasi ISPO semakin luas maka artinya berkorelasi dengan implementasi penerapan paradigma green growth economic dalam praktik pengelolaan industri kelapa sawit. Jika pengelola industri kelapa sawit mengikuti standar sertifikasi ISPO maka akan dapat dipastikan bahwa praktik pengelolaan industri kelapa sawit akan berdasarkan jabaran triple bottom line sebagaimana dimaksudkan dalam paradigma green growth economic.

Momentum penerbitan aturan pelaksanaan dari Peraturan Presiden (Perpres) Nomor 44 Tahun 2020 harus dibarengi dengan evaluasi secara teknis terkait standar prinsip dan kriteria sebagai jabaran triple bottom line yang harus dipenuhi untuk memperoleh sertifikasi ISPO. Dalam hal ini akan terjadi kendala jika ada kemauan dari pengelola industri kelapa sawit untuk memenuhi standar sertifikasi ISPO namun karena adanya ketidaktepatan penetapan standar prinsip dan kriteria maka pemenuhan sertifikasi ISPO akan sulit untuk dipenuhi. Standar prinsip dan kriteria sertifikasi RSPO tidak dapat seratus persen diadopsi dalam sertifikasi ISPO sehingga dalam hal ini perlu dilakukan penyesuaian agar sertifikasi ISPO dapat dipenuhi dan berkorelasi positif dengan implementasi paradigma green growth economic dalam praktik pengelolaan industri kelapa sawit yang lestari (sustain) di Indonesia.

Idealnya dengan terbitnya Peraturan Presiden (Perpres) Nomor 44 Tahun 2020 maka dapat dipergunakan untuk penerbitan aturan di tingkat operasional guna memastikan paradigma green growth economic diimplementasikan dalam praktik pengelolaan industri kelapa sawit. Sifat sertifikasi ISPO adalah sebagai bukti dan indikator bahwa 
praktik pengelolaan industri kelapa sawit di Indonesia telah menerapkan paradigma green growth economic dan prinsip triple bottom line. Artinya saat ini selain perlu melengkapi Peraturan Presiden (Perpres) Nomor 44 Tahun 2020 dengan peraturan setingkat peraturan menteri, dalam hal ini juga perlu dibarengi dengan evaluasi prinsip dan kriteria sebagai dasar penerbitan sertifikasi ISPO.

\section{PENUTUP}

Perpres Nomor 44 Tahun 2020 merupakan momentum evaluasi aspek materiil terkait prinsip dan kriteria pemenuhan sertifikasi ISPO yang lebih tepat. Pasca terbitnya peraturan itu, pemerintah idealnya melakukan tindak lanjut terhadap dua hal, yakni memastikan implementasi paradigma green growth economic dalam praktik industri kelapa sawit melalui penataan, kedua adalah memastikan kepatuhan pengelola industri kelapa sawit.

Kepatuhan berkaitan dengan penegakan hukum, baik sanksi maupun insentif sehingga Perpres Nomor 44 Tahun 2020 harus tegas dan konsisten mengatur paradigma green growth economic. Jika hal itu tidak diimplementasikan, dikhawatirkan praktik pengelolaan industri sawit berdasarkan triple bottom line sebagai jabaran dari paradigma green growth economic tak dapat diselesaikan.

\section{DAFTAR PUSTAKA}

A. G. Wibisana. (2017). “Campur Tangan Pemerintah dalam Pengelolaan Lingkungan: Sebuah Penelusuran Teoritis berdasarkan Analisis Ekonomi atas Hukum (Economic Analysis of Law)". Jurnal Hukum dan Pembangunan Universitas Indonesia, 47(2): 160.

C. A. Van Peursen. (2015). Filsafat Ilmu-Ilmu, diterjemahkan Bernard Arief Sidharta. Bandung: Penerbit Pusat Kajian Humaniora Universitas Katolik Parahyangan.

Darrel Webber. (2015). Opportunities and Challenges in Managing the Palm Oil Industry in Compliance with RSPO Certificate, $1^{\text {st }}$ Edition. Kuala Lumpur: RSPO Publishing.

Esmi Warassih dkk (ed). (2012). Refleksi dan Rekonstruksi Ilmu Hukum di Indonesia. Semarang: Penerbit Bagian Hukum dan Masyarakat Fakultas Hukum Universitas Diponegoro.

Hidayat et. al. (2018). Laporan Tahunan Komisi ISPO Tahun 2017. Penerbit Direktorat Jenderal Perkebunan Kementerian Pertanian.

Hoogan Kevee. (2013). "Understanding Green Economic Growth in the Perspective of Legal Philosophy in Shifting the Paradigm of Environmental Law". American Journal of Comparative Law, 70(2): 190.

https://gapki.id/news/4419/sawit-sumbang-devisa-300-riliun-untuk-negeri-ini-apamaknanya diunduh pada 29 Juni 2020

Iyung Pahan. (2007). Panduan Lengkap Kelapa Sawit: Manajemen Agribisnis dari Hulu hingga Hilir, Cetakan Pertama. Penerbit Penebar Swadaya. 
Jeremy Kartz. (2015). "Green Growth Economic as a New Environmental Paradigm". International and Comparative Law Quarterly Journal, 70 (1): 89.

KTT Bumi (Earth Summit), Rio de Janerio, Brasil tahun 1992: Konsep Pembangunan Berkelanjutan (Sustainability Development)/ Green Growth Economic.

Konvensi Yohannesburg tahun 2002: Paradigma Triple Bottom Line (People, Profit, and Planet).

Minuta Rapat Dengar Pendapat antara Tim Penyusun Naskah Akademik UndangUndang Nomor 18 Tahun 2004 tentang Perkebunan dengan DPR RI, Selasa 20 Januari 2004.

Minuta Rapat Kelompok Kerja (Pokja), Pembentukan Komisi ISPO pada Direktorat Jenderal Perkebunan, 22 April 2009.

Minuta Rapat Kelompok Kerja (Pokja), Penyusunan Perpres ISPO, Kantor Kementerian Koordinator Perekonomian, 15 Mei 2019.

Musdalifah. (2019). Materi Focus Group Discussion (FGD) Penyusunan Perpres ISPO, Kantor Kementerian Koordinator Perekonomian, 5 Maret 2019.

Musdalifah. (2020). Laporan Tahunan Industri Strategis Nasional Kemenko Perekonomian. Jakarta: Kemenko Perekonomian.

Peraturan Menteri Pertanian Nomor 11/Permentan/OT.140/3/2015 tentang Sistem Sertifikasi Kelapa Sawit Berkelanjutan Indonesia (Indonesian Sustainable Palm Oil Certification System/ ISPO).

Peraturan Menteri Pertanian Nomor 19/Permentan/OT.140/3/2011 tentang Pedoman Perkebunan Kelapa Sawit Berkelanjutan Indonesia (Indonesian Sustainable Palm Oil Certification/ ISPO).

Peraturan Presiden Nomor 44 Tahun 2020 tentang Sistem Sertifikasi Perkebunan Kelapa Sawit Berkelanjutan Indonesia.

Raymond Yong Leong. (2015). "Correlation between Environmental Law and Sustainability Aspect in Tropical Countries". University of Malaya Law Review Journal, 51: 97.

Roesdiana Soeharto. (2015). Laporan Tahunan Komisi ISPO, Cetakan Pertama. Jakarta: Direktorat Jenderal Perkebunan.

Salahudin Yacob, et. al. (2012). Handbook of RSPO Certification, $1^{\text {st }}$ Edition. Kuala Lumpur: RSPO Publishing.

Soelthon Gussetya Nanggara et. al. (2017). Evaluasi 6 Tahun ISPO. Forest Watch Indonesia.

Sundram Kumar. (2014). "Comparison between RSPO and ISPO and Their Impact for Palm Oil Industry". Journal of Oil Palm, Environmental and Health, 8(2): 162.

Tan Wisakha. (2016). "Comparing ISPO and RSPO Sustainability Certification Practices in the Palm Oil Industry". Journal of Oil Palm Research, 28: 152. 
Undang-Undang Dasar 1945.

Undang-Undang Nomor 18 Tahun 2004 tentang Perkebunan.

Undang-Undang Nomor 39 Tahun 2014 tentang Perkebunan. 